\title{
経腸栄養剂エンテルード®の使用経験
}

\begin{tabular}{|c|c|c|c|}
\hline 柴 & 基之 ${ }^{1)}$ ·馬場 & 駿吉1) • 柘植 & 勇人1) \\
\hline & 靖浩1) • 河合 & 岝 ${ }^{2)}$ - 梅田 & 敬子2) \\
\hline & 潤3) • 山田 & 葚幹3) - 渡辺 & 暢浩3) \\
\hline & 明4)・伊藤 & 弘美4) • 甕 & 久人 ${ }^{5)}$ \\
\hline
\end{tabular}

\section{Enterued $^{\circledR}$ as an Elemental Diet for Patients with Head and Neck Cancers}

\author{
Motoyuki Hashiba, Shunkichi Baba, Isato Tsuge and Yasuhiro Ito \\ (Nagoya City University Medical School) \\ Takashi Kawai and Keiko Umeda \\ (Ichinomiya City Hospital) \\ Jun Hondo, Masamoto Yamada and Nobuhiro Watanabe \\ (Nagoya Daini Red Cross Hospital) \\ Akira Yokota and Hiromi Ito \\ (Nagoya Municipal Higashi Shimin Hospital)
}

Hisato Motai, Kazuho Moribe, Shinobu Ito and Sohtaro Kamei

(Toyohashi Municipal Hospital)

Twenty eight patients were given an elemental diet $\left(\right.$ Enterued $\left.^{\circledR}\right)$ containing small peptides through a nasal feeding tube. Oral alimentation was difficult for these patients because of head and neck cancer itself or the therapy, surgery and/or irradiation. In 23 of the patients $(82.1 \%)$ the nutritional status was improved. Diarrhea occurred as a side effect in 5 of them (17.9\%), 3 of whom stopped using Enterued ${ }^{\circledR}$. The speed of administration should be carefully controlled to prevent diarrehea.

Key words: Enterued ${ }^{\circledR}$, feeding tube, head and neck cancer

1）名古屋市立大学医学部耳鼻咽喉科学教室

3）名古屋第二赤十字病院耳鼻咽喉科

5）豊橋市民病院耳鼻咽喉科
2）一宮市立病院耳鼻咽喉科

4）名古屋市立東市民病院耳鼻咽喉科 


\section{はじめに}

近年, 経腸栄養法は各種経腸栄養剤の開発に より，その有用性が再認識されてきた。耳鼻咽 喉科領域では, 各種覀性腫瘍患者の術後, 放射 線療法, 抗腫瘍薬剂投与をたは腫瘍の進展に伴 い通常の食物の経口摂取が困難になるケースが 多い。このような症例には, 経中心静脈栄養法 と共に経管経腸栄養法もよく用いられている. とりわけ耳鼻咽喉科領域の症例では, 胃より下 部の消化管には問題のない症例が多く, 経管経 腸栄養法の適応となる症例が多い。

経中心静脈栄養法は近年急速に普及してきた が，強制的に直接静脈内に栄養を投与するため, 十分な管理を行わないと血栓症, カテーテル敗 血症等を若起することがあり, 最德の場合には 患者を死に至らしめることすらあり，とりわけ 長期間に及ぶ場合には，その管理に細心の注意 を要する。また近年, 経中心静脈栄養に伴う問 題として，腸管を使用しないために生ずる bacterial translocationによる感染症がクロー ズアップされてきている112). 経腸栄養法は, 健常時と同様に栄養成分が腸管から吸収されて から代謝経路に入るために，生体にとってはよ り生理的であり, 腸管を用いることから bacterial translocation の問題にも有利であり, そ の管理も比較的容易である. しかし, 経腸栄養 剂の共通の問題点として, 下痢・腹痛・腹部膨 満感等の副作用が出現し易く, 必要充分量の経 腸栄養剂の投与が困難になる場合がある.かか る欠点を改善するべく各種経腸栄養剂が開発さ れてきているが，未だ満足でさるものは少ない．

最近開発されたェンテルード®は, 近年明ら かにされた吸収理論に基づく新しいタイプの経 腸栄養剤である。この薬剤の特徵は, 生体が蛋 白質を消化吸収するときの形態といわれている 低分子ペプチド(ジないしトリペプチド)を窒素 源として用いていることであり，その有用性は すでに外科・内科領域に执いて報告されてい る3) 19).

今回我々は, エンテルード®を耳鼻咽喉科領
域の各種疾患に使用し，その臨床効果を多施設 に沶いて検討したので報告する.

$$
\text { エンテルード®の組成 }
$$

エンテルード®は表 1 に示すように, 窒素源, 糖質, 脂肪, ミネラル, ビタミンがバランスよ く配合された薬剤で, 本剤のみで生体が必要と する栄養素をすべて摂取することが可能である. 窒素源としては, 栄養評価の高い卵白を加水分

表 1 エンテルード®の成分組成

(1 袋 $100 \mathrm{~g})$

\begin{tabular}{|c|c|}
\hline 卵白加水分解物 & $18.4 \mathrm{~g}$ \\
\hline デキストリン & $72.0 \mathrm{~g}$ \\
\hline 脂肪(大豆油：コーン油＝1：1） & $5.0 \mathrm{~g}$ \\
\hline \multicolumn{2}{|l|}{ 電解質 } \\
\hline $\mathrm{Na}$ & $300 \mathrm{mg}$ \\
\hline $\mathrm{K}$ & $300 \mathrm{mg}$ \\
\hline $\mathrm{Cl}$ & $600 \mathrm{mg}$ \\
\hline $\mathrm{Ca}$ & $300 \mathrm{mg}$ \\
\hline $\mathrm{P}$ & $200 \mathrm{mg}$ \\
\hline $\mathrm{Mg}$ & $86 \mathrm{mg}$ \\
\hline $\mathrm{Fe}$ & $2.9 \mathrm{mg}$ \\
\hline $\mathrm{Zn}$ & $1.5 \mathrm{mg}$ \\
\hline $\mathrm{Mn}$ & $0.6 \mathrm{mg}$ \\
\hline $\mathrm{Cu}$ & $0.2 \mathrm{mg}$ \\
\hline \multicolumn{2}{|l|}{ ビタミン } \\
\hline パルミチン酸レチノール & $1000 \mathrm{IU}$ \\
\hline 塩酸チアミン & $1.0 \mathrm{mg}$ \\
\hline リボフラビン & $1.0 \mathrm{mg}$ \\
\hline 塩酸ピリドキサン & $1.0 \mathrm{mg}$ \\
\hline シアノコバラミン & $2 \mu \mathrm{g}$ \\
\hline アスコルビン酸 & $200 \mathrm{mg}$ \\
\hline コレカルシフェロール & $100 \mathrm{IU}$ \\
\hline 酢酸トコフェロール & $30 \mathrm{IU}$ \\
\hline フィトナジオン & $0.5 \mathrm{mg}$ \\
\hline ニコチン酸アミド & $10 \mathrm{mg}$ \\
\hline パントテン酸カルシウム & $2.0 \mathrm{mg}$ \\
\hline 葉酸 & $0.2 \mathrm{mg}$ \\
\hline ビオチン & $50 \mu \mathrm{g}$ \\
\hline 塩化コリン & $20 \mathrm{mg}$ \\
\hline イノシトール & $20 \mathrm{mg}$ \\
\hline $\mathrm{pH} 6.5 \sim 7.5$ & $\mathrm{nl}$ 調製時) \\
\hline 浸透圧 $510 \sim 550 \mathrm{mOsm} / \mathrm{kg}(1 \mathrm{kcal}$ & $\mathrm{nl}$ 調製時） \\
\hline 粘度 $2.4 \sim 2.9 \mathrm{cp}$ & $\mathrm{nl}$ 調製時） \\
\hline
\end{tabular}


解することにより得た低分子ペプチド(ジない しトリペプチドを $70 \mathrm{w} / \mathrm{w}$ 以上含有)を用いて いる. 近年，低分子ペプチドについて，結晶遊 離アミノ酸混合物よりも吸収速度が速く, 吸収 後の門脈血中のアミノ酸レベルが投与組成に近 いことが報告されている20) 31)，糖質には溶解 性，吸収性に優れているデキストリンを用いて いる。脂肪には大豆油とコーン油を $1: 1$ の割 合で混合したものを配合し，必須脂肪酸を必要 充分量投与できるよう工夫されている.

エンテルード®は溶解性が極めて高いため, 従来の経腸栄養剤のような強い撹拌を必要とせ ず，また，常温水にも簡単に溶解する. 更に, 粘性にも優れ，細いチューブを用いても全く支 障を来さない流動性を有している。

エンテルード®を $1 \mathrm{kcal} / \mathrm{ml}$ に調製した場合， 浸透圧は $534 \mathrm{mOsmol} / 1$ となり，結晶遊離アミ 八酸混合物を用いた経腸栄養剤よりも低值であ る。

\section{対象および方法}

\section{1 . 対 象}

表 2 に示す施設にて治療を行った症例で，上 顎癌, 喉頭癌, 舌癌, 咽頭癌等の疾患の手術あ るいは放射線治療のため，もしくは腫瘍の進展 のため，通常の食䬣形態では 1 日に必要なエネ ルギーの経口摂取が困難な症例を対象とした. 症例を表 3 亿示す。

2.エンテルード®の用法および用量

投与方法は ED チューブを経鼻的に胃まで挿 入して投与した。通常本剤 $100 \mathrm{~g}$ を $40 \mathrm{ml}$ とな るように常水または微温湯で調製 $(1 \mathrm{kcal} / \mathrm{ml})$ し，成人標準量として 1 日 400〜600 g (1600〜

\section{表 2 参加施設}

名古屋市立大学耳鼻咽喉科

一宮市立病院耳鼻咽喉科 名古屋第二赤十字病院耳鼻咽喉科 名古屋市立東市民病院耳鼻咽喉科 豊橋市民病院耳鼻咽喉科

（順不同）
$2400 \mathrm{kcal})$ を鼻腔チューブ，胃瘦または腸瘦よ り胃，十二指腸または空腸に 1 日 12〜24時間か けて投与する。投与速度は $100 \sim 150 \mathrm{ml} /$ 時間 とする. 経口摂取可能な場合は 1 回または数回 に分けて投与することもできる。

また，投与開始時は，通常 1 日当り $50 \sim 100$ $\mathrm{g}(200 \sim 400 \mathrm{kcal})$ を低濃度 $(0.5 \mathrm{kcal} / \mathrm{ml}$ 前後 $)$, 低速度 $(100 \mathrm{ml} /$ 時間以下) で投与し，臨床症状 に注意しながら増量して $4 \sim 7$ 日で標準投与量 に達するよらにする。な拈，年齿，体重，症状 により投与量, 投与濃度, 投与速度を適宜増減 する.

\section{3 . 検査項目}

全対象例に対して共通のケースカードを作成 し，患者の原疾患，既往歴，投与前の栄養状態， 投与方法・部位，各種検査值等を記入した。

血液および血清生化学検査では, 赤血球数, 白血球数, ヘマトクリット值, 総蛋白, アルブ ミン，トリグリセリド，総コレステロール， GOT, GPT, LDH, AL-P, $\gamma$-GTP, クレアチ= ン, 尿素窒素, 総ビリルビン, $\mathrm{P}, \mathrm{Na}, \mathrm{K}, \mathrm{Cl}$, Ca 実施した。また，白血球分画りンパ球， $\mathrm{Tf}($ トランスフェリン), $\mathrm{PA}$ (プレアルブミン),



4. 評価項目

担当医師の判断に基ついて, 栄養効果度, 概 括安全度，有用性について評価を行った。

\section{結果}

1. 原疾患の内訳扣よび症例の背景

表 4 亿示すごとく総症例数 28 例であった．性 別では男性が女性の 3.7 倍であり，年齢では 3 分の 2 以上が 60 歳以上の高齢者で占められてい た。原疾患別では，中・下咽頭癌が最も多く約 $1 / 3$ を占め, 舌・口腔癌, 喉頭癌がそれに続い た。その他に分類された原疾患の内訳は，甲状 腺癌 1 例, 癌性髄膜症 1 例, 気管癌 1 例, 食道 癌 1 例であった。

2 . 投与状況

表 5 に示すごとくであり，投与日数は 2 〜 104 日で，平均投与日数は22.9日であった。 


\begin{tabular}{|c|c|c|c|c|c|c|c|c|c|c|c|c|c|}
\hline \multirow{3}{*}{  } & \multirow{3}{*}{  } & \multirow{2}{*}{  } & \multirow{3}{*}{  } & \multirow{3}{*}{  } & \multirow{2}{*}{  } & \multirow{2}{*}{  } & \multirow{2}{*}{ 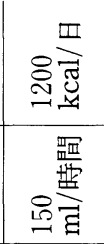 } & \multirow{2}{*}{  } & \multirow{2}{*}{  } & \multirow{2}{*}{  } & \multirow{2}{*}{  } & \multirow{2}{*}{  } & \multirow{3}{*}{  } \\
\hline & & & & & & & & & & & & & \\
\hline & & 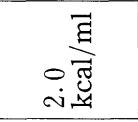 & & &  &  &  &  &  &  &  &  & \\
\hline \multirow{3}{*}{  } & \multirow{3}{*}{  } & 茵 & \multirow{3}{*}{  } & \multirow{3}{*}{  } & 恶 & 焉 &  & 苜 &  &  &  & 邑 & \multirow{3}{*}{  } \\
\hline & & 号焉 & & & 突学 &  & 号点 & 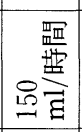 &  & 尺 &  & ஓ要 & \\
\hline & & 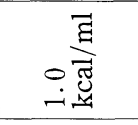 & & &  &  & 韋 &  &  & 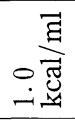 & 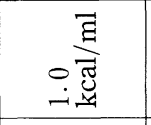 &  & \\
\hline 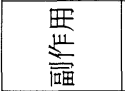 & $\underset{r}{r}$ & 鞦 & 哑 & $\begin{array}{l}\sqrt{x} \\
\pm 1 \\
+1\end{array}$ & 粕 & 救 & 㖪 & 䩳 & 粍 & 粘 & 标 & 救 & 㥠 \\
\hline  & 粕 & 耕 & 敤 & 邦 & 杽 & 耕 & 些 & 湈 & 标 & 峘 & 步 & 些 & 船 \\
\hline  &  & $\begin{array}{l}\square \\
\infty\end{array}$ & $\frac{11}{10}$ & $\frac{\square}{\sigma}$ & 뜽 & 플 & $\frac{\text { 문 }}{\sqrt{5}}$ & $\frac{\pi}{9}$ & 뜽 & $\frac{\text { 미 }}{\sigma}$ & $\underset{9}{\frac{1}{9}}$ & $\frac{\pi}{9}$ & $\begin{array}{l}\text { एᄄ } \\
\text { N }\end{array}$ \\
\hline W & 邦 &  &  &  &  &  &  &  & 㐜 &  &  &  & 羊 \\
\hline  & $\begin{array}{l}\underset{\mathbb{W}}{K} \\
K\end{array}$ &  & 器 &  &  &  &  & $\begin{array}{l}\text { 漹 } \\
\text { 犽 }\end{array}$ &  &  &  & 满 &  \\
\hline 崖 & 靯 & 救 & 粕 & 湈 & 槊 & 救 & 棫 & 耕 & 羏 & 慙 &  & $\begin{array}{l}\text { 盗 } \\
\sqrt{x}\end{array}$ &  \\
\hline$\frac{\text { 船 }}{4}$ & 萧 & 敤 & 粠 & 粘 & 些 & 断 & 耤 & 救 & 嶂 & 稙 &  & 粕 & 目 \\
\hline 整 &  &  &  & $\begin{array}{l}\text { 㗪 } \\
H \square\end{array}$ &  &  &  &  &  & $\begin{array}{l}\text { 㗪 } \\
H \square\end{array}$ &  & $\begin{array}{l}\text { 㵖 } \\
\text { HI }\end{array}$ &  \\
\hline  & $\begin{array}{l}0 \\
\text { in }\end{array}$ & $\begin{array}{l}10 \\
0\end{array}$ & $\stackrel{0}{i}$ & $\stackrel{\circ}{\circ}$ & $\begin{array}{l}\infty \\
\text { ஸे } \\
\text { în. }\end{array}$ & $\begin{array}{l}\dot{0} \\
\dot{\infty}\end{array}$ & $\begin{array}{l}0 \\
\dot{1} \\
\dot{1}\end{array}$ & $\begin{array}{l}\dot{+} \\
\dot{q}\end{array}$ & $\begin{array}{l}0 \\
\dot{0}\end{array}$ & $\begin{array}{l}0 \\
\dot{\theta} \\
\dot{q}\end{array}$ & $\begin{array}{l}0 \\
\dot{0} \\
\dot{H}\end{array}$ & 卢 & $\begin{array}{l}0 \\
\dot{\oplus}\end{array}$ \\
\hline $\begin{array}{l}\overrightarrow{\bar{\sigma}} \\
\# \\
\end{array}$ & $\not X$ & $\not x$ & 略 & 㧽 & 畎 & 畍 & 畍 & 畍 & 凅 & $H x$ & 㧽 &  & $k x$ \\
\hline  & 8 & మి & $\varnothing$ & $\stackrel{\sim}{\sim}$ & $\infty$ & $R$ & 8 &  & ळి & $i$ & 10 &  & 6 \\
\hline  & - & N & $m$ & $\sigma$ & תا & 0 & $\sim$ & $\infty$ & $\sigma$ & $\stackrel{-}{\circ}$ & $\exists$ & $\cong$ & \\
\hline
\end{tabular}




\begin{tabular}{|c|c|c|c|c|c|c|c|c|c|c|c|c|c|c|c|}
\hline  &  &  & 足 & 足 & 近 & 폻. & 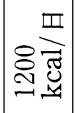 & 造 & 严莺 & 응 & \multirow{3}{*}{  } & 울 & 폻] & 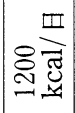 &  \\
\hline  &  &  &  &  &  & 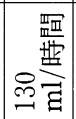 &  &  &  &  & & 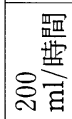 &  & 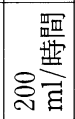 &  \\
\hline  &  & 音 &  &  &  &  & 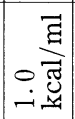 &  & 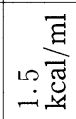 & 苂 & & 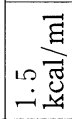 &  &  & $\underset{0}{\overline{\text { g }}}$ \\
\hline 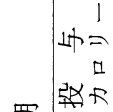 & 蒠 & 号䔍 & 这 & 这 & 造 & 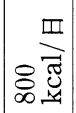 & 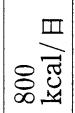 & 플 & 플 & 可 & \multirow{3}{*}{  } & 㥼 &  & 플 & 몰 \\
\hline 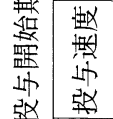 &  & 号学 & 它畐 &  & 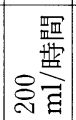 & 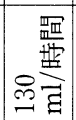 &  & 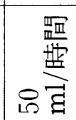 &  &  & & 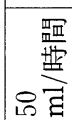 &  &  &  \\
\hline  &  & 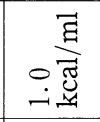 & 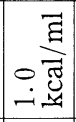 & 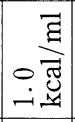 &  &  &  & 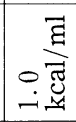 &  &  & & 鸪 & 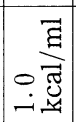 & 咅 & 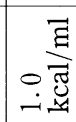 \\
\hline 带 & 进 & 粕 &  & 槑 & 断 & 稙 & 跕 & 敤 & 粘 & $\underset{r}{r}$ & 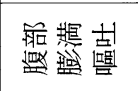 & 䫧 & 夥 & 棉 & 㟖 \\
\hline 䍘 & 断 &  & 标 & 粠 & 断 & 嵲 & 救 & 粕 & 靬 & 断 & 柶 & 嗉 & 耤 & 粘 & 峄 \\
\hline  & 粟 & 땅 &  & $\frac{\pi}{8}$ & $\begin{array}{l}\square \\
\forall\end{array}$ & $\underset{\infty}{\mathbb{1}}$ & 舢 & $\underset{I}{\mathbb{I}}$ & $\frac{11}{6}$ & $\underset{\Xi}{\rightleftarrows}$ &  &  & $\frac{\pi}{\sqrt{3}}$ &  & 愛 \\
\hline Wh & 樏 & 影 & 軫 & 敤 & 敤 &  & 粘 &  &  &  &  &  & 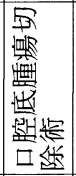 & 颣 &  \\
\hline  & $\begin{array}{l}\frac{\pi \mathbb{N}}{K} \\
K\end{array}$ & K & $\begin{array}{l}\frac{\mathbb{M} \mathbb{K}}{K} \\
K\end{array}$ & 㱐 & $\mathbb{I} \mathbb{W}$ & 政 &  & $\mathbb{I} \mathbb{I}$ & 政 & $\mathbb{4}$ & 涉 & $\mathbb{1 1 \mathbb { N }}$ & $\mathbb{I I N}$ & $\mathbb{\mathbb { M } \mathbb { K }}$ & $\mathbb{1} \mathbb{\Psi}$ \\
\hline 宸 & 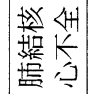 & 断 & 断 & 棫 & 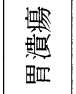 & 旉 & 救 & 敤 & 耕 & 踥 & 粨 & 曑 & 棉 & 路 & 谏 \\
\hline  & 栏 & 嘲 &  & 敤 & 楼 & 敷 & $\frac{\text { 嫼 }}{\text { 监 }}$ & 敤 & 粕 & 紫 & 标 & 监 & 邦 &  & 影 \\
\hline  &  &  &  & 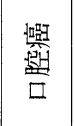 &  &  &  &  & 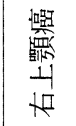 & 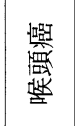 &  &  &  &  & 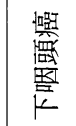 \\
\hline  & $\begin{array}{l}0 \\
\dot{m}\end{array}$ & $\begin{array}{l}0 \\
\dot{m} \\
\dot{H}\end{array}$ & $\begin{array}{l}0 \\
\dot{q}\end{array}$ & $\begin{array}{l}\dot{0} \\
\dot{\forall}\end{array}$ & $\begin{array}{l}0 \\
\dot{6}\end{array}$ & in & $\begin{array}{l}0 \\
\dot{y} \\
\dot{y}\end{array}$ & $\begin{array}{l}0 \\
\dot{4} \\
10\end{array}$ & $\begin{array}{l}0 \\
8\end{array}$ & iv & $\begin{array}{l}0 \\
\dot{0} \\
10\end{array}$ & $\begin{array}{l}0 \\
\dot{8}\end{array}$ & $\begin{array}{l}0 \\
\text { î } \\
\text { î }\end{array}$ & $\begin{array}{l}10 \\
\dot{0} \\
10\end{array}$ & in \\
\hline $\begin{array}{l}\text { 震 } \\
\stackrel{4}{*}\end{array}$ & 個 & 㧽 & 畂 & 貯 & 㧽 & 貯 & 畂 & 㧽 &  & 㽖 & 凅 & 㽖 & 略 & 畂 & 畎 \\
\hline  & $\infty$ & ฮิ & 2 & เా & 8 & $\infty$ & $\stackrel{2}{2}$ & 18 & is & $\ddot{8}$ & 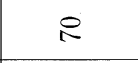 & 8 &  & $F$ & $\stackrel{2}{\circ}$ \\
\hline 寻 & $\Xi$ & $\stackrel{10}{\longrightarrow}$ & 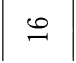 & $\simeq$ & $\stackrel{\infty}{\longrightarrow}$ & $\stackrel{9}{\rightarrow}$ & 尺ి & $\bar{\sim}$ & ๙ิ & $\cong$ & カ &  & $\stackrel{\mathscr{N}}{v}$ & $\lesssim$ & $\stackrel{\infty}{\sim}$ \\
\hline
\end{tabular}


た，1 日の維持量は $800 \sim 1800 \mathrm{kcal}$ で, 平均 約 $1300 \mathrm{kcal}$ であった.

3 . 臨床血液検査成績 (表 6 )

（1）血液一般検査では白血球数が投与後に有 意に減少したが, 赤血球数, ヘマトクリット值 には変化がみられなかった。

（2）血清生化学検査では, 血糖值, 総ビリル ビン值が投与後有意に減少したが，数值は正常 範囲内であった。

表 4 背景因子



（3）総蛋白，AL-P，カルシウムが投与後有 意に上昇したが，数值は正常範囲内であった.

（4）体重は投与前後で変動はみられなかった が， ${ }^{*} \mathrm{RBP},{ }^{*} \mathrm{Tf},{ }^{*} \mathrm{PA}$ は投与後で有意に上昇し ていた.

（5）その他のアルブミン，トリグリセライド, GOT, GPT, LDH, $\gamma$-GTP, 尿素窒素, クレア チニン, $\mathrm{Na}, \mathrm{K}, \mathrm{Cl}, \mathrm{P}$ 等の項目に执いては投与 前と終了後では変化がみられなかった。

*RBP, Tf, PA は Rapid Turnover Protein (RTP) で血中半減期が数時間から数日間と短 く，栄養状態の変動を鋭敏に反映する指標とな る。

\section{4. 総合評価}

（1）栄養効果度 (表 7)

検査結果および臨床症状を担当医師が, 著明 効果, 中等度効果, 軽度効果, 不変, 悪化, 判 定不能の 6 段階に分類し，判定を行った.

28例中15例 (53.6\%)で中等度効果以上を示し， 軽度効果以上は28例中23例(82.1\%)であった。 また，栄養状態が悪化した症例が 2 例(7.1\%)

表 5 投与状況

\begin{tabular}{|c|c|c|}
\hline & & $\begin{array}{l}\text { 症例数(非手術 } \\
\text { 施行症例数) }\end{array}$ \\
\hline \multirow{6}{*}{ 投与期間 } & $\sim 9$ 日 & $8(2)$ \\
\hline & $10 \sim 14$ 日 & $9(2)$ \\
\hline & 15～21日 & $3(0)$ \\
\hline & $22 \sim 28$ 日 & $2(2)$ \\
\hline & $29 \sim 35$ 日 & $1(1)$ \\
\hline & 36 日〜 & $5(3)$ \\
\hline \multirow{7}{*}{$\begin{array}{c}\text { 平均の投与量 } \\
\text { (維持期) }\end{array}$} & ～1200 kcal/日 & $15(6)$ \\
\hline & $1201 \sim 1300 \mathrm{kcal} /$ 日 & $0(0)$ \\
\hline & $1301 \sim 1400 \mathrm{kcal} /$ 日 & $0(0)$ \\
\hline & $1401 \sim 1500 \mathrm{kcal} /$ 日 & $1(0)$ \\
\hline & $1501 \sim 1600 \mathrm{kcal} /$ 日 & $5(2)$ \\
\hline & $1601 \mathrm{kcal} /$ 日〜 & $2(0)$ \\
\hline & 中 止 & $5(2)$ \\
\hline
\end{tabular}


あった。

（2）概括安全度 (表 8 )

28例中，副作用のために投与を中止した症例 は 5 例(17.9\%)であった。副作用により軽度の 下痢を生じたが，その後改善し，投与継続が可 能であった症例は 2 例 (7.1\%)であり, 副作用
もなく安全に投与が可能であった症例は 21 例 (75.0\%)であった．尚，投与を中止した 5 例の 副作用症状は下痢 ( 4 例) と吐き気 ( 1 例)であっ た。

（3）総合判定（表 9）

概括安全度, 栄養効果度の判定により, 担当

表 6 臨床成績調査データ推移

\begin{tabular}{|c|c|c|c|c|c|}
\hline \multicolumn{2}{|c|}{ 検 査 項 目 } & 基＼cjkstart準 & 投与前值 & 投与後値 & $\mathrm{T}$ 検定 \\
\hline \multirow{3}{*}{$\begin{array}{l}\text { 血 } \\
\text { 液 }\end{array}$} & 赤血球 $\quad\left(10^{4} / \mathrm{mm}^{3}\right)$ & 男: 400〜 500 女: $350 \sim 450$ & $354.1 \pm 96.2$ & $352.8 \pm 90.0$ & NS \\
\hline & 白血球 $\left(\mathrm{mm}^{3}\right)$ & $4000 \pm 9000$ & $8114.3 \pm 2851.9$ & $6593.6 \pm 2858.0$ & $\mathrm{P}<0.05$ \\
\hline & ヘマトクリット (\%) & 男: $39 \sim 50$ 女: $36 \sim 45$ & $31.3 \pm 8.5$ & $31.3 \pm 8.0$ & NS \\
\hline \multirow{9}{*}{ 血 } & 血 糖 (mg/dl) & 空腹時70～100 食後 1 時間 140 以下 & $114.4 \pm 51.5$ & $86.0 \pm 35.4$ & $\mathrm{P}<0.01$ \\
\hline & 総蛋白 （g/dl) & $6.5 \sim 8.0$ & $5.7 \pm 0.7$ & $6.3 \pm 0.7$ & $\mathrm{P}<0.01$ \\
\hline & アルブミン & $3.8 \sim 5.1$ & $3.4 \pm 1.6$ & $3.7 \pm 1.9$ & NS \\
\hline & $\begin{aligned} \text { トリグリセライド } \\
(\mathrm{mg} / \mathrm{dl})\end{aligned}$ & $40 \sim 170$ & $101.2 \pm 72.8$ & $98.3 \pm 63.2$ & NS \\
\hline & $(\mathrm{mg} / \mathrm{dl})$ & $120 \sim 250$ & $148.3 \pm 65.0$ & $153.3 \pm 66.5$ & NS \\
\hline & GOT $\quad(\mathrm{IU} / 1)$ & $5 \sim 35$ & $22.1 \pm 12.8$ & $18.8 \pm 12.1$ & NS \\
\hline & $(\mathrm{IU} / 1)$ & $5 \sim 25$ & $14.4 \pm 8.7$ & $14.8 \pm 10.8$ & NS \\
\hline & AL-P $\quad(\mathrm{mU} / \mathrm{ml})$ & $100 \sim 280$ & $163 \pm 82.6$ & $221.1 \pm 175.2$ & $\mathrm{P}<0.05$ \\
\hline & $(\mathrm{IU} / 1)$ & $250 \sim 350$ & $204.8 \pm 132.8$ & $186.6 \pm 105.0$ & NS \\
\hline \multirow{9}{*}{ 清 } & $\gamma$-GTP $\quad(\mathrm{mU} / \mathrm{ml})$ & 40 単位以下 & $27.7 \sim 27.7$ & $32.4 \pm 28.0$ & NS \\
\hline & 総ビリルビン $\quad(\mathrm{mg} / \mathrm{dl})$ & $0.2 \sim 1.2$ & $0.8 \pm 0.4$ & $0.5 \pm 0.2$ & $\mathrm{P}<0.01$ \\
\hline & 尿素窒素 $\quad(\mathrm{mg} / \mathrm{dl})$ & $8 \sim 20$ & $14.1 \pm 6.1$ & $18.3 \pm 12.7$ & NS \\
\hline & クレアチニン $\quad(\mathrm{mg} / \mathrm{dl})$ & 男: $0.8 \sim 1.2$ 女: $0.5 \sim 1.0$ & $1.0 \pm 0.3$ & $1.0 \pm 0.5$ & NS \\
\hline & $(\mathrm{mEq} / \mathrm{l})$ & $135 \sim 148$ & $137.3 \pm 3.7$ & $138.4 \pm 3.3$ & NS \\
\hline & $(\mathrm{mEq} / \mathrm{l})$ & $3.5 \sim 5.5$ & $4.1 \pm 0.4$ & $4.3 \pm 0.5$ & NS \\
\hline & $(\mathrm{mEq} / \mathrm{l})$ & $98 \sim 107$ & $100.1 \pm 5.5$ & $100.3 \pm 3.7$ & NS \\
\hline & $(\mathrm{mg} / \mathrm{dl})$ & $9 \sim 11$ & $6.6 \pm 2.0$ & $7.5 \pm 3.1$ & $\mathrm{P}<0.05$ \\
\hline & $(\mathrm{mg} / \mathrm{dl})$ & $9 \sim 11$ & $6.6 \pm 2.0$ & $7.5 \pm 3.1$ & $\mathrm{P}<0.01$ \\
\hline \multicolumn{2}{|c|}{ 体 重 $\quad(\mathrm{kg})$} & & $49.1 \pm 46.6$ & $49.0 \pm 46.1$ & NS \\
\hline \multicolumn{2}{|c|}{ 白血球分画リンパ球数 } & & $1670.5 \pm 1311.8$ & $1592.5 \pm 895.0$ & NS \\
\hline \multicolumn{2}{|c|}{ Tf } & $210 \sim 390$ & $171.9 \pm 149.3$ & $234.0 \pm 199.1$ & $\mathrm{P}<0.01$ \\
\hline \multicolumn{2}{|c|}{$\mathrm{PA}$} & $10 \sim 40$ & $17.5 \pm 14.9$ & $24.9 \pm 21.1$ & $\mathrm{P}<0.05$ \\
\hline \multicolumn{2}{|c|}{ RBP } & $2.9 \sim 7.9$ & $2.3 \pm 2.0$ & $3.6 \pm 3.1$ & $\mathrm{P}<0.05$ \\
\hline
\end{tabular}


表 7 栄養効果度

\begin{tabular}{|c|c|c|c|c|c|c|c|}
\hline 著明効果 & 中等度効果 & 軽度効果 & 不 変 & 悪 化 & 判定不能 & 合 計 & $\begin{array}{c}\text { 中等度効果 } \\
\text { 以上 }\end{array}$ \\
\hline 1 & 14 & 8 & 1 & 2 & 2 & 28 & $15 / 28 \quad 53.6 \%$ \\
\hline
\end{tabular}

表 8 概括安全度

\begin{tabular}{c|c|c|c|c||c}
\hline \hline 副作用なし & $\begin{array}{c}\text { 軽度の } \\
\text { 副作用めり }\end{array}$ & $\begin{array}{c}\text { 副作用の } \\
\text { ため減量 }\end{array}$ & $\begin{array}{c}\text { 副作用の } \\
\text { ため中止 }\end{array}$ & 合 計 & $\begin{array}{c}\text { 副作用 } \\
\text { 発生頻度 }\end{array}$ \\
\hline 21 & 2 & 0 & 5 & 28 & $7 / 28 \quad 25.0 \%$
\end{tabular}

表 9 有用性

\begin{tabular}{c|c|c|c|c|c||c}
\hline $\begin{array}{c}\text { 極めて } \\
\text { 有用 }\end{array}$ & $\begin{array}{c}\text { かなり } \\
\text { 有用 }\end{array}$ & $\begin{array}{c}\text { やや } \\
\text { 有用 }\end{array}$ & $\begin{array}{c}\text { ぞららとも } \\
\text { いえない }\end{array}$ & 有用性なし & 合 計 & $\begin{array}{c}\text { かなり有用 } \\
\text { 以上 }\end{array}$ \\
\hline 2 & 15 & 5 & 5 & 1 & 28 & $17 / 2860.7 \%$
\end{tabular}

の医師が総合的に評価を行った。また，有用性 に関しては，極めて有用，かなり有用，やや有 用，どちらともいえない，有用性なし，の 5 段 階に分類し, 判定を行った。

その結果，28例中 17 例 $(60.7 \%)$ がかなり有用 以上と判定され，高い有用性を示した。また， 6 例 $(21.4 \%)$ がどちらともいえないと有用性な しであった。

\section{考察}

経腸栄養法と経中心静脈栄養法を長所と短所 の面で比較したとき，経腸栄養法の長所として， カテーテルの長期留置に伴ら敗血症等の重篤な 合併症が少なく，管理が容易な点をあげること ができる。また，非経腸栄養法では食物が通過 しないことにより, 腸管内の細菌叢の变化や粘 液分泌の低下のため, 腸管内の細菌が腸管から 所属リンパ節や血中へ移行する現象 (bacterial translocation)を起こし易くなり，しばしば compromized host において敗血症の原因となるこ とが知られており，経腸栄養法は腸管を働かせ ることにより bacterial translocation を防止す ると言われている122). 頭頸部の悪性腫瘍患者 に执いても，最近の形成外科的再建を含む長時 間に渡る大がかりな手術では，手術侵襲が大き
く, 非特異的な免疫能の低下や, 術後の抗生剂 投与による腸内細菌叢の変化により, bacterial translocation による敗血症などの危険性が高 い状態に陥ることが多いと考光られ，これを予 防する意味からも経腸栄養を行らことには意義 があると考えられる.一方短所としては, 経鼻 チューブを使用することの不快感, 下痢や腹部 膨満感等の副作用があげられる。しかし, 基本 的な適応の考方方として, 腸管の機能が正常で あるならば，できるだけ生理的な状態に近い経 腸栄養法を第一に考えるべきであろら。

従来の経腸栄養剤は窒素源として大豆蛋白, 乳蛋白カゼイン, 結晶遊離アミノ酸混合物など を使用しているが，エンテルード®では栄養評 価が高い卵白を加水分解して得たジないしトリ ペプチド(低分子ペプチド)を $70 \mathrm{w} / \mathrm{w}$ 以上含有 したEWH330を用いている. Matthews と Adibi $^{31)}$ によると, 窒素源として低分子ペプチ ドは腸管からの吸収機序から結晶遊離アミノ酸 混合物よりも吸収速度が速く，また，David ら23によると, 吸収後の代謝に扣いても有効 利用が行われていることが明らかにされたこと から，かねてから経腸栄養剤の窒素源としての 利用に関心がもたれていた。このような理由に 
基づいて開発されたエンテルード®は低分子ペ プチドを窒素源に用いた本邦初の経腸栄養剤で ある。

エンテルード®の脂肪源には大豆油とコーン 油を $1: 1$ の割合で混合したものが $5.0 \mathrm{~g}$ 含有 されて怙り，エンテルード®を長時間単独投与 しても必須脂肪酸が欠乏しないよう考慮されて いる.

今回観察された臨床血液検査値の変動は, 統 計学的に有意のものであっても, いずれも正常 範囲内での変動であり, また症例の半数以上が 術後の使用であったことを考えると，すべてが 本剤の効果であるとすることはできないであろ ら.しかし経腸栄養剤の導入により, 特に初期 の段階では下痢, 腹痛, 腹部膨満感など副作用 が起さる場合がある。今回も, 副作用(下痢・ 発熱)による投与中止例が 5 例あった. 経腸栄 養法導入初期には多少の副作用が発現すること がある.これは投与濃度を希薄にしたり，投与 速度を遅くすることにより防止または改善する ことが可能である. 今回も, 用法・用量を遵守 した症例では副作用は発現しなかった．今回の 投与対象例は寸べて悪性腫瘍の症例であり, か なり全身状態の悪い症例も含まれており，この ような症例に対しては, 消化吸収のよい本剂に あっても他の薬剤と同様に, 個々の患者の状態 から判断した適切な投与条件と, 行き届いた管 理のもとで適用するべきであると思われる，副 作用のために投与を中止しなければならなかっ た症例のらち，2 例はエンテルード®を投与す る以前より全身状態が著しく悪化して和り，そ のことも副作用を莠起した一因と考えられる。 副作用こそ発現しなかったものの, 全身状態が 悪化した症例のうち 1 例ではェンテルード®と 共に, 化学療法剤の併用投与を行っていた. 副 作用のなかで最も多い下痢については, 投与速 度が指定よりも速いと出現頻度が増すことがわ かっている. 全身状態の悪化している例に投与 されることも多いので, 食物であるといら安易 な考えで使用することなく，投与速度について
は指定を守る必要がある。

\section{まとめ}

1）卵白を加水分解して得られた低分子ペプ チド(ジないしトリペプチド)を窒素源とした経 腸栄養剤エンテルード®を 5 施設 28 症例を対象 に投与した。

2 ）上顎癌, 喉頭癌をはじめとする経口から の栄養摂取が不可能な症例に対してェンテルー ド®平均投与カロリ一約 $1300 \mathrm{kcal} /$ 日，平均 投与日数 22.9 日投与した.

3 ) 担当医師の判断による栄養効果度の判定 では中等度以上の栄養改善効果が 28 例中 15 例 (53.6\%)に拈いて認められた。

以上のことから, 耳鼻咽喉科領域に和ける栄 養障害や栄養維持が難しい症例に対して有意な 栄養改善が認められた。 また, 正しい用法・用 量に基づき, 患者の状態から判断した条件にて 投与を行えば，エンテルード®は臨床上有効で 且つ安全な製剤であると考えられた。

\section{参考文献}

1) 井上純雄, 石田祐一, 内田久則: 栄養管理法と Bacterial Translocation. 外科 $53: 710,1991$.

2）青井東呉, 五関謹秀: 癌治療洳ける栄着管理. Pharma Medica $10: 111 \sim 115,1992$.

3）小林清典, 勝又伴栄, 渡辺隆司, 他 : 活動期》 ローン病に対する経腸栄養法の有用性 一成分 栄養と半消化態栄養剤の比較一. Digestion \& Absorption $13:$ 149 153, 1990.

4）綾部時芳, 盧田知史, 垂石正樹, 他：クローン 病に対する成分栄養剤投与に上る経腸栄養の有 用性. Digestion \& Absorption 13:158 162, 1990.

5）田村和民, 平川博之 : 吸収不良症候群と経腸栄 養. Digestion \& Absorption 13:141 144, 1990.

6）沖田極, 児玉隆浩, 多田正弘, 他: 内科サイ ドに打ける経腸栄養片 T-3 30 の使用経験. JJPEN $6: 325,1984$.

7）水野裕支：外科的肝障害時にお斿る経腸栄養に 関寸る臨床的, 実験的研究. 名市医大誌 38 : $77 \sim 98,1987$.

8）五関謹秀, 小野寺時夫：低分子ペプチド配合経 腸栄養剤 (T-330) の長期使用経験. JJPEN 5 : 
$619 \sim 625,1983$.

9）五関謹秀，小野寺時夫：低分子ペプチド配合経 腸栄養剤 (T-330) による胃癌・胃全摘例の術後 栄養管理 一各種栄養指標の推移を中心に一. JJPEN 5 : 611 618, 1983.

10）堀部和夫, 真島吉也, 田代亜彦, 他 : 低分子へ プチドを窒素源としたエレメンタルダイエット を用いた術後栄養管理. JJPEN 5: 503〜 512， 1983.

11）水間公一, 島津雄一, 角 敏博, 他 : 手術前経 腸栄養法の臨床的検討一窒素源としてのアミ ノ酸と小ペプタイドの臨床使用について一. 外 科と代謝・栄養 $17: 415 \sim 421,1983$.

12）小野寺時夫, 平井慶徳, 真島吉也, 他 : 低分子 ペプチドを窒素源とする経腸栄㕌剂 (T-330)の 多施設臨床治験 I - - 般外科一. JJPEN 6 : $67 \sim 82,1984$.

13）山川 満, 前田 純, 小嶋邦昭, 他 : 経管栄㡺 剂 T-330 の臨床治験. JJPEN 6 : 61 66, 1984.

14）小林展章, 谷村 弘, 稲本 俊, 他: 低分子へ。 プチド経腸栄養剤の栄養評価に関する基礎的・ 臨床的研究 (II) 一T-330の臨床的応用とエレ ンタール®の比較一. Arch Jpn Chir 53:133 $\sim 144,1984$.

15）岡本和美, 森 昌造, 新津来一, 他: 新しい経 腸栄養剂 T-330 とェレンタール との比較検討. JJPEN 6 : 223〜230, 1984.

16）岡村健二, 大熊利忠：低分子ペプチドを用いた 新経腸栄養剂 T-330の臨床使用経験. JJPEN $6: 759 \sim 766,1985$.

17）五関謹秀，小野寺時夫：低分子ペプチドを窒素 源とした経腸栄養剤を用いた術後栄養管理— 上部消化管癌を対象としたェレンタール®との 比較臨床一. JJPEN 8 : 359〜367, 1986.

18）溝手博義, 掛川暉夫, 山名秀昭, 他 : 食道, 胃 癌術後の栄養管理 一殊に低分子ペプチド配合 経腸栄養剂の応用一. JJPEN 7:885 894, 1986.

19）平井慶徳，小野寺時夫，真島吉也，他：低分子 ペプチドを窒素源とする経腸栄養剤 (T-330) の 多施設臨床治験 II 一小児外科一. JJPEN 6 : 83 95, 1984.

20) Hara H, Funabiki R, Iwata M, et al : Portal absorption of small peptide in rats under unrestrained conditions. J Nutr $114: 1122 \sim 1129$, 1984.
21) Craft IL, Geddes D, Hyde CW, et al : Absorption and malabsorption of glysin and glysin peptide in man. Gut $9:$ 425 437, 1986.

22) Adibi SA and Phillips E : Evidence for greater absorption of amino acids from peptide than from free form in human intestine. Clin Res $14: 446,1968$.

23) David BA, Silk MD, Fairclough PD, et al : Use of a peptide than free amino acid nitrogen source in chemically defined "elemental" diets. JPEN 4 : 548 553, 1980.

24) Masima Y, Horibe K, Oshiba I, et al : Studies of the absorption of "small peptide" and free amino acids in elemental diets. Clin Nutr 3 : $17 \sim 21,1984$.

25) Newey $\mathrm{H}$ and Smith $\mathrm{DH}$ : Intracellular hydrolysis of dipeptides during intestinal absorption. J Physiol $152: 367 \sim 380,1960$.

26) Lis MT, Matthews DM and Carpton RF : Effects of dietary restriction and protein deprivation on intestinal absoption of protein digestion products in the rat. Br J Nutr 28 : 443 446, 1972.

27) Cook GC : Effect of synthemic infections on glycylglycine absorption rate from the human jejunum in vivo. Br J Nutr $32: 163 \sim 167,1974$.

28) Crampton RF, Lis MT and Matthews DM : Sites of Maximal absorption and hydrolysis of two dipeptides by rat small intestine. Clin Sci $44: 583 \sim 594,1973$.

29) Adibi SA : Intestinal transport of dipeptides in man ; relative inportance of hydrolysis and intact absorption. J Clin Invest $50: 2266 \sim 2275$, 1971.

30) Adibi SA and Soleimanpour MR : Functional characterization of dipeptide transport system in human jejunum. J Clin Invest $53: 1368 \sim$ 1374, 1974.

31) Matthews DM and Adibi SA : Progress in gastroenterology; peptide absorption. Gastroenterology $71: 151 \sim 161,1976$.

\footnotetext{
(原稿受付: 平成 5 年 2 月 12 日 原稿採択: 平成 5 年 3 月 5 日 急載 別刷請求先 : 羽柴基之 干467 名古屋市瑞穂区瑞穂町川澄 1 名古屋市立大学医学部耳鼻咽喉科学教室
} 